\title{
AMERICAN SOCIETY OF CIVIL ENGINEERS
}

Founded November 5, 1852

\section{TRA NSA CTIONS}

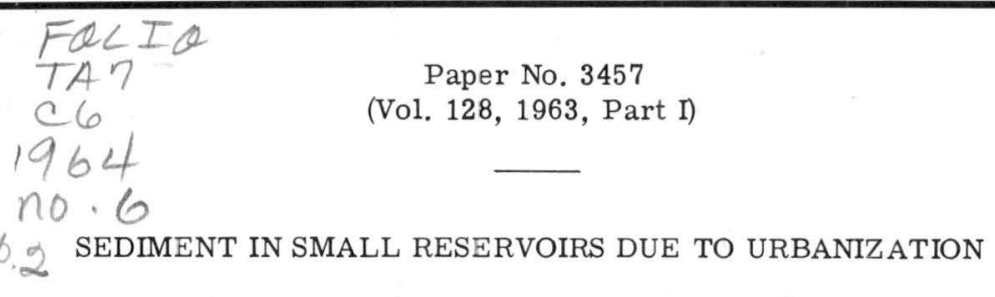

By Harold P. Guy1 and George E. Ferguson,2 F. ASCE

\section{SYNOPSIS}

Expanding urbanization activities may cause serious sediment deposition in small reservoirs. An example is that of Lake Barcroft near Washington, D. C., where 19 acre-ft or 25,000 tons of sediment has been deposited for each square mile of completed residential construction. Factors affecting the sedimentology processes in areas under urbanization are found to be similar to, but more difficult to evaluate than, those applying to rural conditions.

\section{INTRODUCTION}

Sediment derived from natural and agricultural erosion has always given varying degrees of concern to those who plan, finance, or manage water reservoirs. A third source of sediment threatens to reduce further the useful life of many reservoirs downstream from urban centers. This newly recognized source is the result of the increasing quantity of soil material exposed or reshaped by modernearth moving equipment during the construction phases of urban development. The inevitable widening of stream channels after urbanization is an additional source of sediment.

Note.-Published essentially as printed here in March 1962 in the Journal of the Hydraulics Division as Proceedings Paper 3070. Positions and titles given are those in effect when the paper was approved for publication in Transactions.

1 Hydr. Engr., Quality of Water Branch, Water Resources Div., U. S. Geol. Survey, Washington, D. C.

2 Div. Hydrologist, Atlantic Coast Area, Water Resources Div., U. S. Geol. Survey, Arlington, Va.

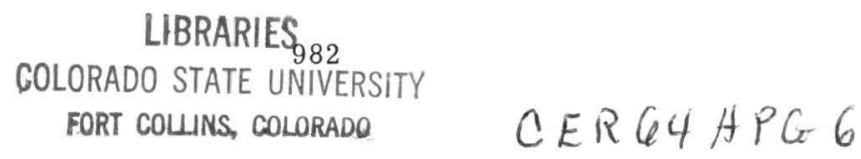


Certain observations, measurements, and theoretical considerations by which the nature and magnitude of this growing problem may be better understood are presented herein. More precise and complete scientific reporting must await further quantitative studies and better understanding of the natural processes and principles at work. Many planners and other public officials are already concerned with the problem of urbanization-induced sediments. Better knowledge of the magnitude and nature of the problem should point in the direction of some remedial measures.

In the early 1920's large areas now (1960) occupied by urban communities were open farm land. By the year 2000 it is logical to assume that additional large rural areas will have been urbanized. The forces motivating this increasingly rapid rate of urbanization are already well publicized. Although urban centers have been gradually expanding throughout the life of the Nation, the pace has greatly quickened during the last two decades. The general migration of an expanding population to urban environments and livelihoods is well under way. Added to this is the desire on the part of many families for nearby semi-rural environments free from the congestion of city centers. The relatively low value of agricultural and forest land, in contrast to the high cost of space in a city, is an additional stimulant to "urban sprawl."

The first public evidence of urbanization is usually residential construction on the fringe of the already developed metropolitan area. Greatest activity is seen in places along, or easily accessible to, existing main highways. Construction of shopping centers, highways, and other service facilities generally follows. Construction activity is commonly dispersed, with some areas already completed while others remain somewhat in the "natural" state, because of the leap frogging process of advancing urbanization.

During construction, large quantities of earth material or subsoil are exposed. These are usually many times more erosive than is topsoil, which, in its natural state, is further stabilized by vegetation. Man-made banks and terraces are of ten near the "angle of repose" of the subsoil and fill materialand, hence, are particularly vulnerable to erosion and bank slides. Contractors may well be aware that gullied banks must be repaired and small deltas removed as a part of the clean-up at a construction site. Yet the construction industry and the public seem to be largely unaware of the greater and more enduring damage of choked stream channels and reservoir deposition at downstream points.

The number of reservoirs of varying size scattered within and reasonably close to metropolitan areas tends to increase as urbanization increases. The larger of these reservoirs, usually financed with public funds, are commonly used for public water supply, public recreation or flood control, or for multiple purposes. Smaller reservoirs are usually privately owned and serve a variety of water-supply and recreational needs. All are vulnerable in varying degrees to deposition of fluvial sediments derived from upstream construction areas. Legislative events such as the Water Supply Act of 1958, the Watershed Protection and Flood Prevention Act of 1954, and the recommendations of the Senate Select Committee on Water Resources stimulate the building of reservoirs. Many of these are certain to be close to urban centers.

\section{SEDIMENTOLOGY AND EXPOSED SUBSOIL}

On a freshly graded area of exposed subsoil, rainfall of an intensity greater than the infiltration capacity will theoretically cause a surface accumulation 
of water. Before and during the build-up of this rainfall excess, the kinetic energy of the raindrops causes a large quantity of dispersion of both water and soil material or sediment. The impact and dispersion result in a sealing of the surface. Hence, the infiltration capacity of the exposed subsoil is many times less than for "natural" or "protected" soils. The sheet of accumulated precipitation accumulates quickly and flows over the surface with its load of "splashed sediment."

The sheet flow soon finds its way to small rills, where resistance to flow is lessened and velocity of flow increased, making possible active erosion of the rills and subsequent movement of sand particles as well as the fine particles of silt and clay. Storm flow in rills on steep slopes is capable of moving coarser material such as gravel. In the rills, as in other larger channels, the fine particles of silt and clay remain in complete suspension. The sands may be moved by intermittent or by continuous contact with the stream bed, or even in complete suspension. The processes of erosion, transportation, and depositionare continuous in the channels and in the reservoirs. Sorting of the sediments is a by-product of the balance between the transporting power of the flowing water and the settling rate of the sediment particles.

\section{LAKE BARCROFT-A CASE HISTORY}

Before examining other general problems involved in the effects of urbanization on sedimentology, it is advantageous to examine what has happened to a reservoir near Washington, D. C. Lake Barcroft, located in Fairfax County, Va., and approximately 8 miles from downtown Washington, was completed in 1915 as a reserve water supply for Alexandria, Va. Use as a water-supply reservoir was discontinued in 1950, at which time the lake was purchased by the Lake Barcroft Corporation for real estate development. The drainage basin covers approximately $14 \mathrm{sq}$ miles. The lake near the dam is approximately $400 \mathrm{ft}$ wide and $65 \mathrm{ft}$ deep. Backwater extends up Holmes Run for 1.4 miles and up Tripps Run for 0.7 mile.

Surveys of sediment deposition in the reservoir, as reported by Holeman and Geiger, 3 show that the original surface area of the lake was 115 acres. On the basis of the first survey in 1938, the area decreased only 0.4 acre during the first $23 \mathrm{yr}$ of operation. In 1942, the spillway was raised $5 \mathrm{ft}$ which increased the lake area to 135 acres. The second survey in 1957 showed an area reduction of approximately 6 acres, mostly as a result of delta formations at the main channels of inflow. The dramatic increase in sediment deposition between the first and second surveys is attributed to residential construction in the vicinity of the lake and in the basin upstream.

With respect to quantity of sediment deposition in the reservoir, the average rate of accumulation was 3.68 acre-ft per yr prior to 1938 , and 10.41 acre-ft per $\mathrm{yr}$ in the $19 \frac{1}{2}$-yr interval between the surveys of 1938 and 1957 . The total accumulation was 85 acre-ft for the first interval and 203 acre-ft for the second. The "normal" or rural rate of accumulation during the second interval is assumed to be $1 / 3$ that of the first interval because of a large reduction in cultivated land and better land use practices. Sediment accumulation during the latter $19 \frac{1}{2}$-yr interval is, then, approximately 24 acre-ft from "normal"

3 "Sedimentation of Lake Barcroft, Fairfax County, Va.," by J. N. Holeman and A. F. Geiger, TP 136, U. S. Soil Conservation Service, 1959, p. 1. 
erosion and transportation and approximately 179 acre-ft from the residential construction.

During the interval between 1938 and $1957,68 \%$ or 9.5 sq miles of the basin was urbanized. The conclusion is then reached that each square mile passing through the construction cycle processes of clearing, grading, building, and seeding results in an accumulation of approximately 19 acre-ft of sediment in the reservoir. At 1,300 tons per acre- $\mathrm{ft}$ or $60 \mathrm{lb}$ per cu $\mathrm{ft}$, this is 25,000 tons per sq mile or 39 tons per acre.

Holeman and Geiger also report that the mean annual runoff into the lake is approximately $17 \mathrm{in}$. It is assumed here, on the basis of unpublished investigations of nearby Rock Creek and the Brandywine Creek at Wilmington, Del $_{0}$, that $3 / 4$ of the runoff is from ground water flow and $1 / 4$ is surface runoff or storm flow. Hence, between 1938 and 1957 the 235,000 tons of sediment from construction sources was carried into the lake by approximately 250,000 acre$\mathrm{ft}$ of water. This is an average of approximately $700 \mathrm{ppm}$ in the $17 \mathrm{in}$. of runoff. However, the sediment is carried mostly in the storm runoff portion, which would then result in an average of $3,000 \mathrm{ppm}$ for this $4-1 / 4 \mathrm{in}$. of the flow.

If there is visualized one specific square mile of construction which is completed in one year, and yielding the average 25,000 tons and $17 \mathrm{in}$. of runoff previously mentioned, the mean concentration of sediment in storm runoff and ground water flow moving into Lake Barcroft would be approximately 20,000 ppm. The concentration would be approximately $86,000 \mathrm{ppm}$ from this square mile of construction for the storm runoff portion only.

\section{VIEWS OF URBAN CONSTRUCTION}

The nature of sedimentation and more particularly of erosional patterns from highway and residential construction in the vicinity of Washington, D.C., are illustrated by Figs. 1-4. Extensive areas of exposed subsoil as a result of cuts and fills are a common sight in this region. The aerial photograph (Fig. 1) shows the extent of the clearing, the removal of natural soil, and the alteration of topography for construction of the highway between a new airport and Washington, D.C. The right-of-way in this case is $400 \mathrm{ft}$ wide, covering an area of approximately 49 acres per mile. Construction schedules are such that the graded surface of unprotected sediment is exposed to the erosive action of the raindrops and the sheet, rill, and channel flow of rainfall excess. Fig. 2, showing the intensive bank erosion on this highway due to exposure of the steeply cut slopes during the winter months of 1960-61, is one illustration of the results of these erosive forces. A study of the spacing and small size of the rills at the top of the bank compared with the bottom of the bank shows that they were cut by water originating on the graded surface rather than from flow originating above the bank.

The movement of "front yard" sheet flow, and the consequent movement of sediment into rills and small channels on graded soil in a residential area, is shown in Fig. 3. The swift and turbulent nature of the flow indicates its power, not only to carryeasily the fine sediment from the sheet erosion and bank cutting, but also to move sand and gravel. Some of the fine sediment may be caught in vegetation along banks farther downstream or in the deeper portion of a reservoir. The coarse sediments, on the other hand, may be deposited in 
the form of deltas at the confluence of a small stream with a larger stream, or at the head of a small reservoir, as illustrated by Figs. 4(a) and 4(b). Finer sediment has been carried beyond the sites shown in Fig. 4.

Sediment moving in storm runoff from a 58 -acre drainage area at Kensington, Md., has been measured at a drop spillway by the senior writer since

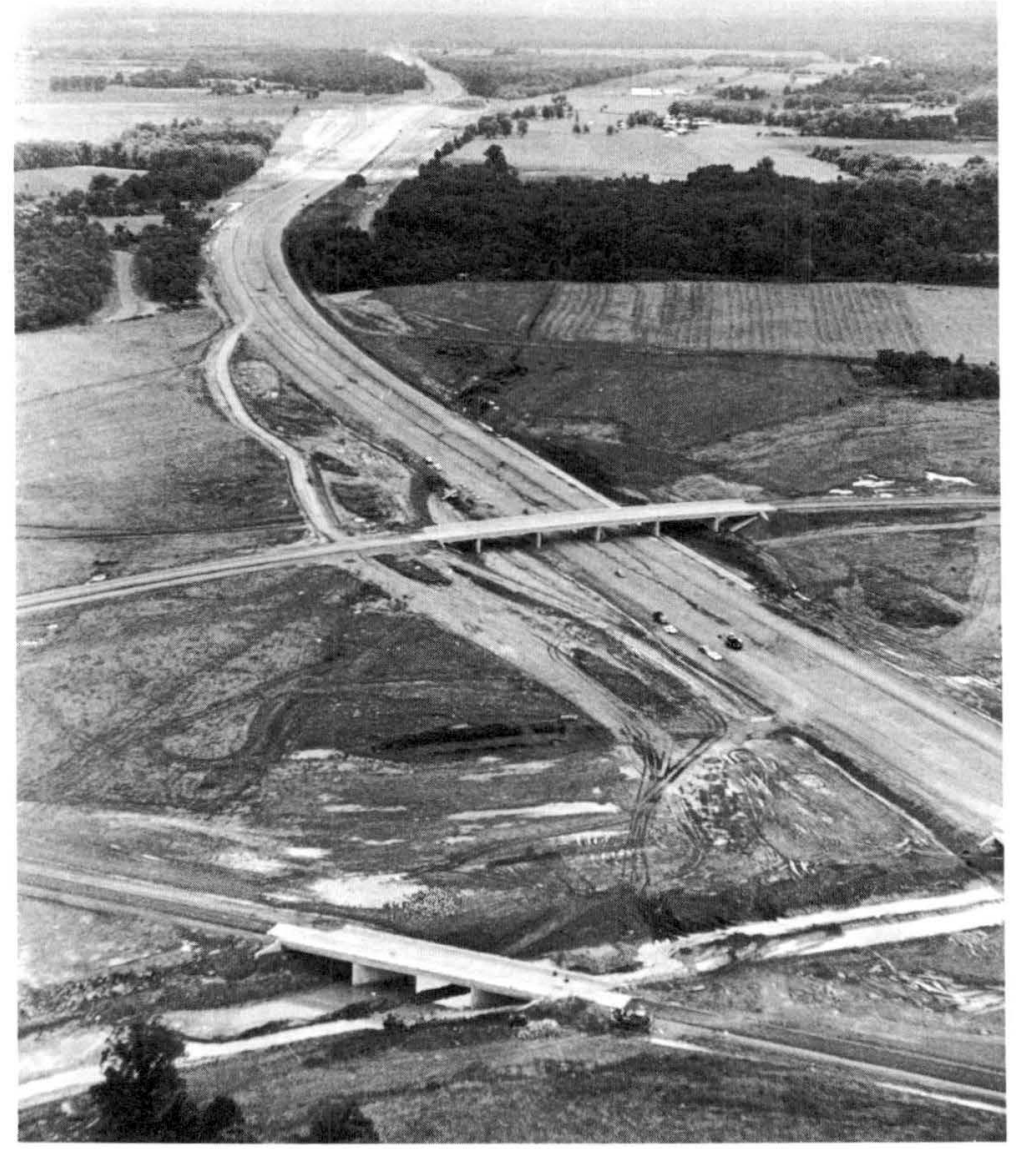

FIG. 1.-AN AERIAL VIEW OF PARTIALLY COMPLETED HIGHWAY FROM DULLES INTERNATIONAL AIRPORT LOOKING EAST TOWARD WASHINGTON, D. C., JUNE, 1961

April, 1959. From this date until October, 1960, construction of streets and houses exposed from 2 acres to 10 acres of subsoil, and caused some natural waterways to be altered. As one group of houses was completed, construction 
was begun in a new area. A sufficient number of storm events was sampled to show the trend of sediment discharge with progression of the construction cycles. The concentration of sediment in nearly 100 such samples ranges from $680 \mathrm{ppm}$, after most construction was completed and during a slow steady rain, to $105,000 \mathrm{ppm}$ during an intense thunderstorm when approximately $15 \%$ of the 58 acres was exposed. Visual examination of changes in the condition of the

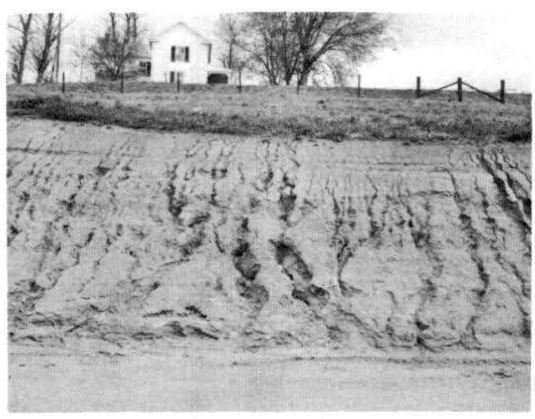

FIG. 2.-EROSION ON A CUT BANK AS A RESULT OF EXPOSURE DURING THE WINTER OF 1960-61 FOR HIGHWAY SHOWN IN FIG. 1

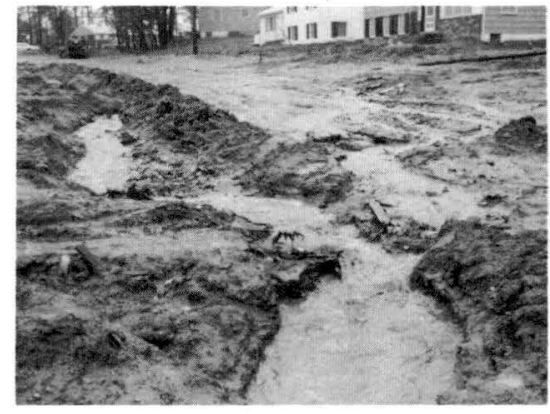

FIG. 3.-SHEET AND RILL FLOW FROM RAINFALL EXCESS ON AN UNPROTEC T ED AREA DURING RESIDENTIAL CONSTRUCTION

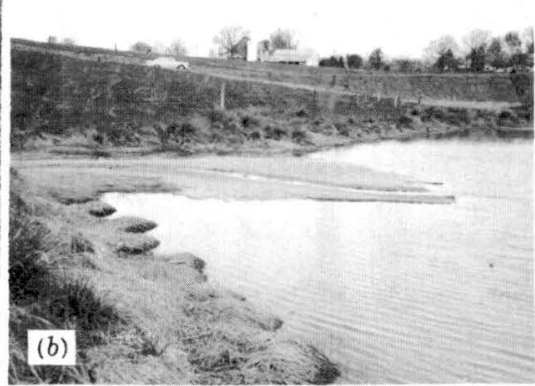

FIG. 4.-DEPOSITION OF COARSE SEDIMENT IN A STREAM AND A SMALL RESERVOIR FROM HIGHWAY AND STREET CONSTRUCTION

stream bed shows that gravel coarser than the 1/4-in. nozzle of the sampler is also transported from the basin.

The measurements at Kensirgton, Md., indicate that the movement of sediment from concentrated residential construction may exceed 50,000 tons per sq mile, or double that entering Lake Barcroft as described earlier. Measurements of sediment movement from several "natural" drainage basins in Pennsylvania and Virginia near the Washington area show that the yield is gen- 
erally less than 200 tons per sq mile per yr. Two important reasons account for the difference between the area at Kensington and that of Lake Barcroft: First, the intensity of construction at Kensington was greater and, hence, delivery of eroded sediment to the stream was more complete; and second, the greater slope of the streams in the smaller drainage area insured greater transport efficiency with a minimum of channel aggradation. A third, but probably less important reason, is that some of the fine sediment passed over the dam and thus was not included in the Barcroft measurements.

\section{FACTORS AFFECTING URBANIZATION-INDUCED SEDIMENT PROCESSES}

An understanding of how sediment enters the watercourses from areas under urbanization and moves downstream to reservoirs requires careful attention to a variety of environmental factors that, either singularly or in combination, may greatly affect the rate and manner of erosion, transportation, and deposition. Logically, the present knowledge of these factors and processes in the more familiar "natural" basins should be fully utilized and combined with knowledge learned of the nature of urbanization and its effects on sedimentology. The following are some of the important factors likely to affect the quantity of sediment eroded from construction during a specific storm event.

1. The intensity and duration of rainfall. A measure of rainfall energy was found by Walter H. Wischmeier and Dwight D. Smith 4 to be a useful parameter in evaluating soil erosion from cropland.

2. The antecedent soil and hydrologic condition. Perhaps the familiar antecedent precipitation index will serve the need.

3. The relief or the length and degree of slope.

4. The particle sizes of sediment in the eroding areas, in transport, and deposition.

5. The season of the year as it affects land use, precipitation characteristics, and water temperature.

6. The channel capacity for carrying sediment.

7. The composition and concentration of dissolved solids in the streams and reservoir as they affect the settling velocity of particles.

8. The size, depth, shape, and water level of the reservoir.

9. The geology and the degree of weathering and erodibility of unconsolidated sediments.

10. The intensity and dispersion of construction.

11. The construction methods and street layout.

Considerable knowledge is available concerning the first nine of these factors in field erosion, transport, and deposition problems. However, the last two, relating to the nature of construction for urbanization, seem complex and in need of intensive study.

The variations in quantity of sediment moving downstream with time from areas under urbanization are broadly related to the phases and types of construction activity within the total period of development. The smaller the area, the more likely that construction is a part of a single fully coordinated effort,

4 "Rainfall Energy and Its Relation to Soil Loss," by W. H. Wischmeier and D. D. Smith, Transactions, Amer. Geophysical Union, Vol. 39, No. 2, 1958, p. 285. 
such as a housing development or a shopping center. The period between ground breaking and the growing lawns, or paved areas, is likely to be less than two or three years. The construction area exposed to erosion normally builds up rapidly to a peak and then gradually diminishes. Sediment moves downstream with a similar pattern.

The larger area normally embraces a combination of types of development requiring up to ten years or even longer to complete. It will include the "small area" construction projects referred to previously, but these will be interspersed with custom or individual residential and commercial construction and the needed networks of highway and water and sewage lines. Sediment movement from this large area reflects the complex composite of many construction activities underway at any one time. This observed difference in rate and period of development between areas of different size is illustrated in Fig. 5.

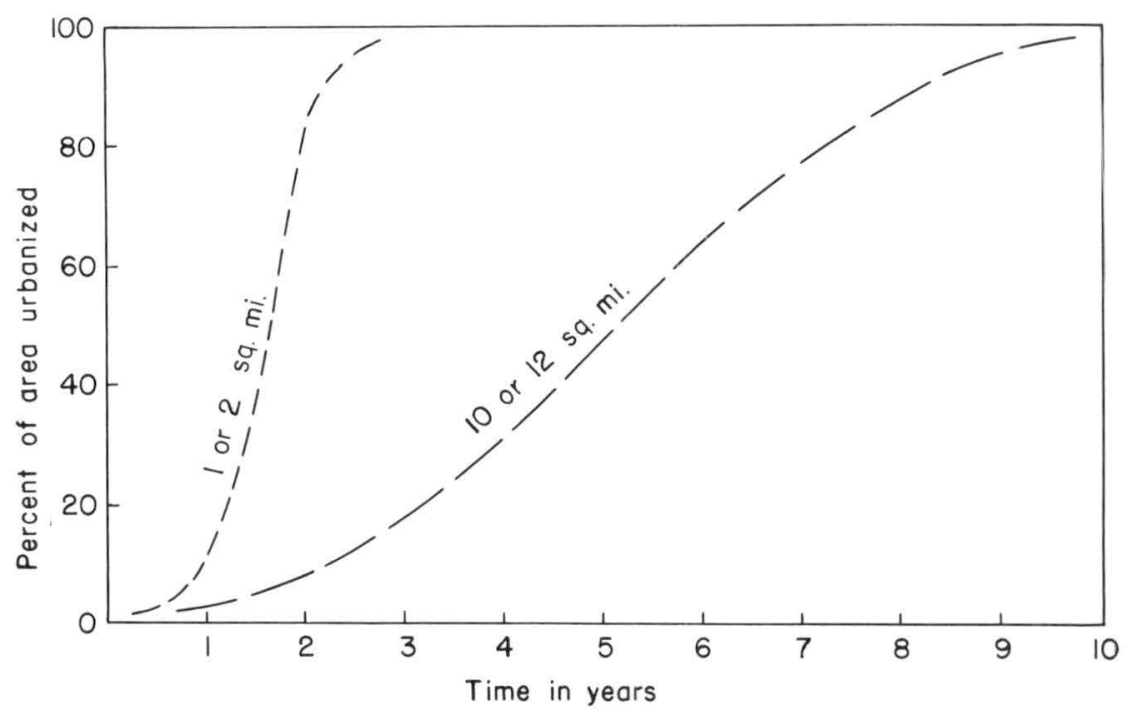

FIG. 5.-THEORETICAL RATE OF URBANIZATION

Sediment movement resulting from the typical development of an area of "custom-built" residences has been observed to be considerably different from mass housing projects. "Custom-built" houses under construction at any one time normally are dispersed geographically, and it takes a comparatively long: time for all lots to be occupied. As a result, erosion and transportation of sediment are materially reduced. Sheet and rillerosion is decreased because of the shorter length of slopes within the boundary of the single lot. Channel erosion and sediment transport is reduced because of reduced runoff due to infiltration of rainfall on lawns and vacant lots largely protected by vegetation. In addition, sediment from these scattered building sites may follow broken segments of drainage channels, in various degrees of completion, or may be largely deposited among dense vegetation on the intervening lot. 
By contrast, the drainage features of an area of mass housing or other multiple construction projects consist of relatively long slope lengths of exposed sediments and long continuous reaches of constructed drains with predesigned gradients. This environment results in intensive sheet and rill erosion and large transport capacity due to the increased runoff and more efficient channel system.

The total quantity of sediment released, the manner in which it travels with time, and the size of particles moved may be affected by construction specifications and the contractor's methods. Customarily few contract specifications call for the slopes of exposed cuts or fills to be stabilized within short periods of time after construction is begun. Yet such measures are known to reduce greatly the total quantity of sediment moved from a construction area by storm runoff. More compact time scheduling of excavation for streets, various utilities, and sidewalks reduces the exposure period of the bare soil to erosion. Temporary earth barriers that reduce the velocities of sediment-laden storm waters may cause a beneficial deposition of the coarser particles.

The particular design of a street network influences sediment movement. Street layouts that follow or cut gradually between topographic contours are subject to less sediment loss during construction than those that are more nearly normal to contours.

\section{POST-URBANIZATION SEDIMENT}

Knowledge of the magnitude and significance of the continuing rate of sediment transport in streams and deposition in reservoirs becomes important under the post construction period. The writers have observed that storm flow in streams draining urban and suburban areas appear to have a near "normal" sediment load. Such "normal" sediment discharge is insignificant if it is in the order of 200 tons or 300 tons per sq mile per yr, in contrast to the 25,000 tons to 50,000 tons discharged during construction.

On the other hand, it is logical to assume that sediment discharge may increase as a result of natural channel widening to carry the increased rate and quantity of runoff from the now more impervious drainage basin. A. L. Tholin, F. ASCE, and Clint Keifer, M. ASCE, 5 in presenting a procedure for determining rainfall-runoff relationships, use diagrams showing an increase in peak rate and quantity of runoff with increase in impervious areas. R. W. Carter, F. ASCE, 6 found that the rate of flood discharge for a recurrence interval of $2.33 \mathrm{yr}$ was 1.8 times greater under suburban development than for rural areas in the Washington area. Luna P. Leopold, F. ASCE, and Thomas Maddock, Jr., F. ASCE, 7 in a study of the hydraulic geometry of stream channels, found that channel width, depth, and velocity increase with water discharge; in other words, the increased flow has increased energy to erode the stream channel banks and thereby change the character of the channel geometry. Another

5 "Hydrology of Urban Runoff," by A. L. Tholin and Clint J. Keifer, Transactions, ASCE, Vol. 125, 1960, p. 1308.

6 "Magnitude and Frequency of Floods in Suburban Areas," by R. W. Carter, Professional Paper 424-B, U. S. Geol. Survey, Dec. 1961, p. 9.

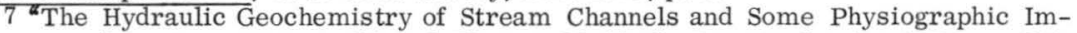
plications, " by Luna B. Leopold and Thomas Maddock, Jr., Professional Paper 252, U. S. Geol. Survey, 1953. 
logical reason for expecting the streams to widen after urbanization is based on the expected increase in size of particles lining the channel from the eroded subsoils during construction, as well as the findings by S. A. Schumm, 8 showing that the width-depth ratio increases with decrease of silt and clay in transport. Natural channel widening is, therefore, a logical source of sediment for deposition in reservoirs after drainage areas have been urbanized.

During and following urbanization, the increased runoff and sediment load causes an increase in the ratio of coarse to fine sediment deposition in the reservoirs. This is the result of reduced reservoir trap efficiency of fine sediments due to stronger density currents set up by higher concentrations of fine sediment. The increased quantity of water and sediment mixture displacing the clear water in the reservoir also is likely to result in reduced trap efficiency. Measurements of sediment moving through a small reservoir in $\mathrm{Ne}-$ braska, 9 having a drainage area of 145 acres, showed that the trap efficiency was approximately $61 \%$ when the inflow was 20,000 ppm to 25,000 ppm of silt and clay and $83 \%$ when the inflow was $11,000 \mathrm{ppm}$ to $16,000 \mathrm{ppm}$.

During the time when these fines are transported through the channel systems and the reservoir, much of the coarser sediment will be deposited in the channel system. These coarse deposits are then available for transport by the more intense storm flows after the construction is completed. The coarse sediment in transport will also increase because of the greater proportion of coarse sediment exposed to erosion in the urbanization areas than occurs with natural soils. The increased proportion of coarse sediment deposition in the reservoir will cause a greater proportion of the total deposition to occur in the headwaters of the reservoir.

\section{CONCLUSIONS}

A study of the problems involved in the deposition of sediment in small reservoirs from urbanization leads to the following conclusions.

First, it is apparent that the use of rural land for urban expansion is increasing rapidly. This is the product of increasing rates of population growth, larger house and lot sizes, more commercial parking areas, and other evidences of higher living standards.

Second, many drainage basins with reservoirs used for water supply and recreation are in the path of urbanization. Such urbanization involves a wide range of efforts and facilities ranging from the construction and maintenance of homes retaining little or none of the original vegetative cover to public parks retaining much of their original vegetive cover.

Third, construction exposes large areas of soil and sub-soil which greatly intensifies the processes of erosion, transportation, and deposition of sediment. Residential construction caused approximately 25,000 tons of sediment to deposit in Lake Barcroft for each square mile urbanized. Residential construction, in another area in metropolitan Washington, caused approximately 50,000 tons of sediment movement in streams per square mile.

Fourth, theory for understanding the nature and complexity of the urbanization-induced sediment problem has not been established. Present knowledge

8 "Effect of Sediment Characteristics on Erosion and Deposition in Ephemeral Stream Channels," by S. A. Schumm, Professional Paper 352-C, U. S. Geol. Survey, 1961.

9 "Fluvial Sediment in Whitehead Watershed and Whitehead Reservoirs, Nebraska," by J. C. Mundorff and P. R. Jordan, Circular 406, U. S. Geol. Survey, Tables 5 and 6. 
concerning sediment erosion, transportation, and deposition in the "rural basins" must be combined with new knowledge of the nature of urbanization processes. The effects of intensity and dispersion of construction, for example, are logically important factors, but there are no data for evaluating them.

Fifth, after urbanization, a significant source of sediment deposition in reservoirs would probably be from the natural channel widening caused by increased rate and quantity of water discharge, and caused by an increase in sediment particle sizes lining the stream bed and banks.

Sixth, deposition in a reservoir probably will be of coarser sediment when associated with urban construction than when associated with rural conditions. This is the result of the exposure of coarser sediments to erosion, the increase in transport capacity of drainage systems, and the high concentrations of fine sediments being carried through the reservoir during the early phases of construction.

Further studies should be made of the cause as well as the effect of reservoir sedimentation from upstream urbanization. Large geographic differences will likely be revealed. Findings reported herein are predominately for the Washington, D.C., area. More knowledge can be gleaned from past and current studies of sedimentation initiated for other purposes. More measurements of fluvial sediments are to be encouraged. To be meaningful these should be carefully correlated with environmental and causative factors. 